\title{
Paradoxes of Aspiration for and of Children in Primitive and Isolated Cultures
}

\author{
D. CARLETON GAJDUSEK
}

National Institutes of Health, Bethesda, Maryland 20892

\begin{abstract}
"Escape from Paradise" might better have been my title! My experience has been, specifically, in Melanesia, including New Guinea; Solomon Islands; New Hebrides; in the most remote, least visited Polynesian and Micronesian islands and atolls; in remote Indian villages and camps of South and Central America; with Australian aborigines; agricultural and transhumance tribesmen of Iran; Afghanistan, and remote tribal peoples of India, China, Siberia, and Africa.

In Melanesia, man lives in preliterate communities of about 100 persons, 50 to 300 usually, rarely more. Man dies as an adult without having seen 1000 persons in his human horizon. With incest taboos broad and a complex kinship algebra proscribing relationships, mating is anything but random and choice of partners is very limited. Often there are only a few individuals, sometimes only one, in the whole social world available as an appropriate spouse.
\end{abstract}

In most primitive cultures, it takes about six successful pregnancies with live births to produce two offspring who survive to themselves have offspring. In hunter-gatherer and hoe and digging stick primitive agriculturist groups from tropical jungles and equatorial deserts to the Eskimo and Aleut arctic fisherman and hunters, this is a roughly correct figure. In fact, the pattern of life in primitive groups often depended on the high infant mortality not to overburden a mother, on whose work the survival of her family depended. Higher infant and child mortalities were usually seen only in postagricultural revolution, crowded rural and urban settings, or when devastating "virgin soil" epidemics have resulted from new pathogens being introduced to nonimmune groups.

With introduction of clean water supplies and better food preservation, as well as modern therapy for infections, the unanticipated survival of two-thirds or more of the infants and children has often placed an impossible load on the mother with resulting increased malnutrition in infants and toddlers-perhaps in the whole family.

All primitive groups had, before contact with highly technologically developed cultures, an age pyramid with half or more of the population under 15 years of age-sometimes under 12 years. This often produced a lifestyle of dependence on the contribution of children to the feeding and economy of the family. It has, furthermore, usually produced a personality that expects, enjoys, and needs living in close contact with many kinsmen, not, as with us, a dependence for material and psychologic support on the limited nuclear family.

\section{THE FIRST PARADOX}

Today with portable TV, radio, cinema, Coca-Cola, cold beer, and rock music invading the most remote parts of Papua New Guinea, West New Guinea and Indonesia, Solomon Islands and New Hebrides, Aleutian Archipelago, Amazon and Orinoco jungles, and the most remote areas of China, India, and Africa, there is only one major aspiration of the normal, intelligent child in a primitive and isolated culture or community, and that is to get out!
Anthropologists, sociologists, physicians and pediatricians, missionaries, and administrators and philosophers still believe in the "noble savage" and the pristine uncontaminated life of "island paradises", but all kids have seen, as in the Aegean Islands of long ago, that "where the action is, ain't here!" The longing of childhood is to leave.

The small primitive isolates of the world have been sending their youth off-for good-for millenia. Disenfranchised, disillusioned, deracinated, alienated man of the 20th century deprived of his human heritage of an extended family, by the thin icing of recent societies relying upon a nuclear family, is amazed that these denizens of Paradise should want to fly to our Hell. If we were less cynical, we would bring a few choice morsels of our modern, high-tech culture to them. This may satisfy the aged, but not the aspiring young, who intelligently want to get at the sources of rock music, McDonald's hamburgers, Coca-Cola, transistor radios, TV, and moon shots-"to where the action is"-as did the ancient Aegean islanders.

When the main action center of civilization was no longer PreMycenean Crete and Thera, those young Aegean Islanders who could, cleared out and went to the new centers of power, commerce, art, and culture, as they continue to do in recent centuries. Witness our 10 million illegal aliens and ask how many want to go back home. If you are an American Indian, suggest that Europeans, Asians, and Africans return to the utopias from which they came; or if one is an indigene of New Zealand, Australia, or Siberia, ask the same. Even the Indians, Indonesians, Algerians, and now the Malays, New Caledonians, Fijians, and Black South Africans would like to get rid of those who have found their climes greener pastures than the traditional homes from which they came.

My first paradox is that the inhabitants of "Paradise"-on Pacific atolls and island villages, surrounded by kinsmen, from the tropics to the arctic-want as youths to get into the "action," even if it be in urban slums and ghettos with all the loneliness, frustration, and anxiety of modern high-tech cosmopolitan urban life.

Witness Auckland, the largest Polynesian city in the world, with more Mauris than all the rest of New Zealand, more Samoans, Tuomotuans, and Cook Islanders than remain back on their home islands-now new nations-and not trying to go home!

My unpopular message is that which gave rise to the departure of the prodigal son-and, as Gide pointed out, who but his father wanted him to be a failure abroad and return admitting this?and the Anglo Saxon Dick Woodington, and the German children following the Pied Piper of Hameln.

\section{A SECOND PARADOX}

My second paradox is that although man values his family, his nation, his culture, his traditions, and his origins above all else, and much of his heroism is based on such devotion, patriotism, and ethnocentricity, yet the most primitive world teaches us, as does an unbiased cold eye at our own, that man is a cultural 
improvisor, and that culture, language, myth, art, and social organization are "cheap," and easily reinvented under strong necessity by a few unrelated humans from diverse cultures. Any small group composed of members from the most diverse societies can form a new culture, new language, art, social structures, morality and mores, costume, and cuisine that become the new roots and history for the people in only a part of a human lifespan. Examples of such rapid transformations of culture are legion: Trojan women to Mycenean Greeks; Greeks to Romans; Cathagineans, Gauls, Dacians, Slavs, Germans, and Celts to Romans; Sabine maidens to Romans; Romans ceding to the "Barbarians" and the Christians; Anglo-Saxons to the Norman French; Mongols to Chinese (Yuan Dynasty); Ainu to Japanese; Jews and Moslems in Spain of 15 th century (los Reyos Catolicos) to Catholics; Jews in China; Portugese in Japan; All we "Americans"; Amerindians; and "renegade" British Puritan, and French American colonists who became Indians (Metis).

This is also an unpopular message to all representing, and well-anchored in, established cultures and societies-all defending their nation, religion, or culture-but it is the lesson of history. In the microcosm of over 1000 cultural and linguistic groups in the Melanesian and Micronesian South Pacific, we see such total changes in a language and culture, religion, and mores in a fraction of a lifetime again and again on a smaller scale.

The basic optimism of seeing man as a cultural improvisor pays homage to his adaptability and potential for survival-it should be one of the qualities most to be admired in man, for it endows him with potential for his own success and genetic survival in most adverse circumstances. He does not become a full prisoner of whatever culture he is born into, acculturated to, and with which he has learned to live in conformity, usually with all the emotions of filial pride, dedication to family, religion, and patriotic zeal. He may give his life defending these, but those who survive social catastrophy adapt when they must, and those who cannot, succumb. Most adapt!

\section{A THIRD PARADOX}

In many, particularly Micronesian, cultures, dissimilation and discretion are the cardinal virtues inculcated in a young childalready at toddler age. A child must learn to tell adults what they want to hear, to never offend feelings or produce shame. The truth, unbridled honesty, can be damaging, harmful "vices" in such a culture where truth needs to be twisted, omitted, or altered to prevent insult, shame, resentment, or disgrace. The same for actions. A child learns to do what adults expect and want, not what some absolute standard of morals or virtue dictates. A justice that is not absolute and a mortality that accommodates much backsliding is essential in these cultures.

Dissimilation, discretion, perceptive awareness of the needs and desires of others, consideration and lack of self-assertionbut not honesty, truthfulness, forthrightness, and constancyare the virtues. Tell and do what people really want you to do, not what they say they want. Sensitive and perceptive children and toddlers, with the feelings of others more their concern than their own gratifications, are what they get by their style of child rearing. Childhood sexuality is considered to be lusty, healthy, and playful, and participation of children in sexual activities with their peers as well as with adults is acceptable and considered the normal road to maturity in these less-inhibited cultures. From the days of the earliest explorers, whalers, China traders, and missionaries, these people have found that all Europeans value and enjoy these qualities in their children and youths, no matter how much lip service they give to the more Puritan virtues.

\section{A FOURTH PARADOX}

We aspire to ethnic identity. We wish to revive the language, legends, song, dance, myths, and cuisine of our fathers, and yet a people with more than 2000 years of literacy and one of the most inflected, refined, and poetic languages of mankind has elected to abandon its language, for its children, and to turn to an artificial, Esperanto-like synthetic language, created in the past half-century from unwritten Bazaar Malay by a commission, namely, Bahasa Indonesia. All this to maintain the Javanese Empire in 20 th century Indonesia against the rising tides of national freedom and self-determination. Thus, the 60 million Javanese have forsaken their traditional language and culture to preserve the union of many peoples and tongues in their insular new empire. They have amalgamated themselves into one nation with the use of a newly created synthetic national language, native to none of its peoples. Children of many educated Javanese can no longer speak to their grandparents, much as second- or third-generation Americans can no longer speak to their central European relatives.

With their independence after World War II, they adapted an orthography that is essentially Dutch, spelling their capital city "Djakarta," their main island "Djawa," and using "dj" or " $\mathrm{j}$," "tj" for "ch" (now "c"), and "oe" for long "u". In the mid-1970s they realized the cumbersomeness of this and simplified the alphabet to a more phonetic 24-letter alphabet. This required revising and reproducing every school book in the nation and even every map, calendar, and phone book in the nation and all other alphabetized records. The paradox lies in the apparent ease in which a large population with an unusually long history of literacy and an elaborate and complex civilized culture has made such immense change as to abandon the main vehicle of their culture, their complex, highly inflected language. Millions of second and third generation Americans testify to the same event.

\section{MY FINAL PARADOX}

Many of us are called upon to advise underdeveloped countries such as the World Bank and WHO concerning medicine, nutrition, sanitation, and education. We almost invariably focus quickly on rural and urban poverty, rural illiteracy, outmoded agriculture, indigent and hungry, famines and droughts, and high infant mortality, and the compelling needs in health care delivery to the most remote of their villages. That the modern university hospital and medical center facilities with CAT scan for head injuries, intensive care units, modern laboratories for reliable antibiotic sensitivity typing of bacteria cultures, virus diagnostic facilities, radiation therapy centers for cancer therapy, and other aspects of high tech modern medicine of world class standard should be their extravagant goal is often ridiculed. We are concerned more with their grass roots problems than with the dignity and success of their elite and intelligencia and with their minorities of already trained and capable people in their capital cities.

We gain little credit or respect from these educated nationals for trying so hard to gain "points" for entry into our own Heavens by saving lives in their own outback. Indonesians have never forgiven the Dutch for concentrating on teaching them to be teachers of their own illiterate and doctors for their own sick, but leaving the education in law, engineering, banking, business, and politics to the Dutch and denied to their own millions. With education in politics, business, law, engineering, and banking to levels of international capability, they can easily run their own show, buy their foreign teachers and doctors, far better trained than their own, and enter with pride, far more quickly, into the international community with dignity and without the need of missionaries, medical aid teams, food relief, and dole. Few developing world countries want the developed countries to concentrate on their poor and dying, their ailing, remote rural agriculture and village economy, their primitive village wells and latrines, and even their epidemics. Instead, give them the ability to control their own destiny in industry, politics, business, and law, and they will buy and negotiate for their needs, as they can see them, in these "humanitarian" fields of endeavour, where we gain for ourselves such self-satisfaction ("Points of Heaven") for 
activities that have little impact on their future, and often cause them to be enslaved and subservient for longer.

The recent political situation in Fiji has caught what remains of the British Empire unprepared and the rest of the Western and Eastern major cultures by surprise. It should not have been so.

The British brought Indians to Fiji to be coolies in the sugar cane fields and teachers and clerks in the colonial administration. These visitors, invited to stay and settle by the British, not by the Fijians, have become Indian Fijians and retain their racial and cultural identity, as do the Fijians. Now, after a democratic election has moved the Indians into dominant political power, a military coup has ousted the elected Indian government and returned it to Fijian control. As one might suspect, the military and police have remained in the control of the Fijians.

Fiji and the University of the South Pacific and its Medical School could easily fill all of its available places with only Indian youths if admission were based on scholastic attainment and Cambridge Standard Examination grades ( 0 and $M$ levels). However, the Fijian population, which still numbers about half the people on their island, insisted that at least half of the students be Fijian and not all Indians.

The Fijians thus gain their share of university entries by this quota system, if not by scholastic attainment and diligence as students. The anomaly and the danger of no Fijians in the Fijian University does not escape the Indians. However, the situation is yet worse. When it comes to scholastic performance at the University, in terms of academic attainment, constancy of effort, noninfringement of University rules, absenteeism, etc., the Indians once again mostly succeed and the Fijians mostly fail! In order not to have mostly Indians and few or no Fijian graduates, once again the Fijians must demand that an equal number of both groups are passed and graduated. The anomaly and danger of no Fijian graduates from the Fijian University again does not escape the Indians.

The parliamentary system of the Western world has been challenged just before it has succeeded in removing Fijians from major participation in their own government and from control of their own land. The same situation has been the case with parliamentarian and egalitarian democratic systems depriving the Mauris, the Australian Aborigines, and the American Indians of their own homelands. It serves best those who created it and brought it in by religious and political proselytilization in the name of humanitarianism to counteract the "barbarism" they encountered in tribal life.

The French liberté, egalité, and fraternité seem to fail completely in time, perhaps largely because of the most patent lack of the last virtue, fraternité.

The cry is that the previously tribal peoples have failed to embrace fully the Hebraic-Christian-Moslem virtues and the necessary commitment to oath, contract, and honesty, upon which the commercial world and the Western world thrive. Without honoring contract, how can indentured servitude survive?

The situation is very, very similar in New Caledonia with the French Colons and the New Caledonian Melanesians, and most evident between the Palestinians and the Jews in Israel, the Tamil and Senhalese in Sri Lanka, and the South African Blacks and the European South Africans; similarly, between the Quechua and Aymara Indians of the Bolivian Altiplano and the Europeans. Anywhere a tribal indigenous culture that was non-Western has been partially but incompletely assimilated into European mores, morals, religions, values, and lifestyles, this situation will prevail as long as the Western values set the framework for gaining access to the positions of power in politics, finance, academia, and advisory positions. The same situation prevails in Malaysia with the Chinese Malaysians as it does with the small Chinese minority in Indonesia. The Chinese quickly dominate the scene in commerce, finance, and scholastic attainment wherever they go. They encounter little competition or desire for competition from the Malaysians-Javanese-Sumatrans-Balinese and other Indonesian hosts. It is largely because the life of diligence, frugality, competitive striving, honesty, and constancy is little respected by the traditional Malaysian culture.

Sharing within a wide kinship network, deference to age and rank, ability to revel and entertain, ability to lose oneself in ecstasy and trance, a social wisdom with abnegation, tactfulness, lack of self-assertion and competitive social climbing, and concensus decision-making, with clouded, implicit rather than explicit, even undefined solutions, as in family affairs, are the traditional and respected ways of life; not personal individuality and agrandisement and triumph over others. Even sports without the overriding desire to win and beat the others all the time or the desire not to exceed others in one's academic attainment and single out oneself as different or superior characterize Malaysian and Micronesian personality.

These virtues do not lead to success in Western institutions, in Western academia, in Western or Asian trade, commerce, art, or competitive sports. They might be termed the "vices" in competitive academias, business, and orderly Western democratic politics.

\section{PARADOXES}

The first aspiration of a normal child living in isolated primitive paradise is to get out! The security of an extended family and village life surrounded by close relatives appears to us to be better than alienation in modern industrial urban society, yet many of the young in isolated communities would escape from their utopian certainty of future and security of traditional village life, and its ennui, for the excitement and anxiety of the urban metropolis.

Reared and bred to be devoted to his family, community, language, and culture, a child can discard it all easily, and with others from alien cultures can learn or invent new language and social order and become devoted to these. Restated: Despite lifesacrificing heroism and martyrdom to preserve his cultural values, man is a cultural improvisor, who can recreate a new social order or adapt to an alien one in a part of a lifetime. Traditional culture, handicraft, and art are part of the web of life of primitive cultures and these are endowed with mystical significance, but the youth prefer the junk of the modern industrial societies. Traditional music, dance, and ritual represent the soul of a people-but rock music and modern Hawaiin music on the electric guitar are better.

Although we try to inculcate competitive individuality and honesty and forthrightness in our children, many South Pacific cultures inculcate personal effacement and noncompetitive deference to others, perceptive recognition of the desires of others, and the associated virtues of discretion and dissimilation. They value but little tactless honesty and forthrightness. They dislike assertive individuality. We say we abhor these character traits in children, yet they have seen that whether it be priest or Protestant missionary, captain or seaman, beachcomber, physician, merchant, or government official, all fall willing victims to the seductive graces of their youths of both sexes, and enjoy it; all find their children compellingly charming.

Developing countries need good universities, modern hospitals, and other centers of excellence in all fields, particularly in engineering, law, medicine, agriculture, and education, in spite of their enormous expense, more than they need grass roots aid at a village level, i.e. primary health care delivery, as a focus for assistance from developed nations. Otherwise, the aspirations of their educated elite cannot be met and intelligent youths, with only 19 th century facilities available to them and to their families, are wise to emigrate. Only with centers of excellence at home can developing countries solve their problems in their remote unelectrified areas themselves. 